\title{
In Vitro Screening of Medicinal Plants Used in Mexico as Antidiabetics with Glucosidase and Lipase Inhibitory Activities
}

\author{
Guillermo Ramírez, ${ }^{1,2}$ Miguel Zavala, ${ }^{3}$ Julia Pérez, ${ }^{3}$ and Alejandro Zamilpa ${ }^{2}$ \\ ${ }^{1}$ Biological and Health Sciences Ph.D. Program, Division of Biological Sciences and Health, Universidad Autónoma \\ Metropolitana-Xochimilco, 14387 Mexico, DF, Mexico \\ ${ }^{2}$ Southern Biomedical Research Center (IMSS), Argentina 1, Col. Centro, 62790 Xochitepec, MOR, Mexico \\ ${ }^{3}$ Department of Biological Systems, UAM-Xochimilco, Calzada del Hueso 1100, Col. Villa Quietud, 04960 Mexico, DF, Mexico
}

Correspondence should be addressed to Alejandro Zamilpa, azamilpa_2000@yahoo.com.mx

Received 27 May 2012; Revised 20 August 2012; Accepted 27 August 2012

Academic Editor: Benny Tan Kwong Huat

Copyright (C) 2012 Guillermo Ramírez et al. This is an open access article distributed under the Creative Commons Attribution License, which permits unrestricted use, distribution, and reproduction in any medium, provided the original work is properly cited.

This work shows the inhibitory effect on glucosidase and lipase enzymes of 23 medicinal plants described as traditional treatments for diabetes in several Mexican sources. Hydroalcoholic extracts of selected plants were evaluated at $1 \mathrm{mg} / \mathrm{mL}$ for glucosidase and $0.25 \mathrm{mg} / \mathrm{mL}$ for lipase inhibitory activities, respectively. Camellia sinensis, acarbose, and orlistat were used as positive controls. Dose-response curves were done with the most active species. Sixty percent of all tested extracts inhibited more than $25 \%$ of $\alpha$-glucosidase activity. C. sinensis displayed an inhibition of $85 \%\left(\mathrm{IC}_{50}=299 \mu \mathrm{g} / \mathrm{mL}\right)$, while Ludwigia octovalvis and Iostephane heterophylla showed the highest inhibition $\left(82.7 \%, \mathrm{IC}_{50}=202 \mu \mathrm{g} / \mathrm{mL}\right.$ and $60.6 \%, \mathrm{CI}_{50}=509 \mu \mathrm{g} / \mathrm{mL}$, resp.). With respect to lipase activity, L. octovalvis and Tecoma stans were the most inhibiting treatments $\left(31.4 \%, \mathrm{IC}_{50}=288 \mu \mathrm{g} / \mathrm{mL} ; 27.2 \%, \mathrm{IC}_{50}=320 \mu \mathrm{g} / \mathrm{mL}\right)$, while C. sinensis displayed $45 \%$ inhibition $\left(\mathrm{IC}_{50}=310 \mu \mathrm{g} / \mathrm{mL}\right)$. These results indicate that a high proportion of plants used in Mexico as treatment for diabetes displays significant inhibition of these digestive enzymes.

\section{Introduction}

Since the second half of the 20th century, most societies are experiencing an epidemic-like increase in chronic degenerative diseases, mainly cardiovascular, cancer, and type 2 diabetes mellitus. In 2008, type 2 diabetes mellitus (t2DM) world cases were estimated at 348 million individuals, with a striking increase among children and adolescents living in low- and middle-income countries [1]. Such global surveys show that in spite of many important discoveries about the pathophysiology of the disease, reported in the last 15 years, its incidence continues to climb and surpasses even the boldest projections.

Several new types of drugs have been introduced as treatments in the last decade (dipeptidyl peptidase- 4 inhibitors, glucagon-like peptide- 1 analogs, and cannabinoid receptor type 1 antagonists) and it seems that glucose renal reabsorption inhibitors will be the next available pharmacological therapy [2]. While bariatric surgery is the most successful approach in some cases, this measure is invasive, somewhat risky ( $0.5-3 \%$ mortality), and very expensive [3]. Glucosidase and lipase inhibitors have been available for a long time as prescription medicines, but their use is infrequent as a treatment for diabetes. The leading glucosidase inhibitor, acarbose, is used scarcely due to its low efficacy in decreasing glycemic levels; the lipase inhibitor orlistat is approved for weight loss but is not indicated as a diabetes control measure. Both compounds elicit unpleasant side effects and are not well accepted by both patients and physicians [4]. On the other hand, it has been shown that some plant preparations, containing glucosidase and/or lipase inhibitors, are devoid of these side effects but are still clinically useful (touchi, green tea) $[5,6]$. Our interest in glucosidase inhibitors led us to search for lipase-inhibiting species, following the glucolipotoxicity hypothesis, which states that chronic or postprandial glucose and free fatty 
acids, in supraphysiological blood concentrations, contribute to beta cell failure [7]. This work explores whether a sample of medicinal plant extracts, selected by the Mexican ethnomedical knowledge as "antidiabetic," contain significant levels of both inhibiting enzymatic activities and if these in vitro assays are able to identify novel candidates for further phytochemical and in vivo pharmacological analyses aimed at developing prototypes of phytodrugs for diabetes control.

\section{Materials and Methods}

2.1. General. Corn starch (S-4186); 5,5'-dithiobis(2-nitrobenzoic acid) (DTNB, Ellman's reagent; D-8130); pancreatic lipase (type II, crude, from porcine pancreas, L-3126); 2,3-dimercapto-1-propanol tributyrate (DMPTB, 97\%; cat:282413); albumin (fatty acid free, bovine, A6003) were obtained from Sigma-Aldrich (St. Louis, MO, USA). Acarbose (Sincrosa, Alpharma, Mexico City, Mexico) and orlistat (Lysthin, PsicoFarma, Mexico City, Mexico) were used as positive controls. Glucose was measured with a quantitation kit (Glucosa-TR) from Spinreact (Girona, Spain). Solvents were obtained from Merck (Darmstadt, Germany); miscellaneous chemicals (salts, buffers, solvents) were purchased either from Merck or Sigma.

2.2. Bibliographical Sources Used for Plant Selection. The ethnomedical compilations of Cano [8], Aguilar and Xolalpa [9], Andrade-Cetto and Heinrich [10], and RomeroCerecero et al. [11] were consulted to select species used as treatment for diabetes in Mexico. L. octovalvis was incorporated in view of information from healers and plant dealers from the south of the state of Morelos, México (Xochitepec, Jojutla, and Zacatepec areas).

Most of the 23 vegetal species were collected in the state of Morelos, Mexico, and voucher specimens were deposited at the IMSS Herbarium (IMSSH), where identity was assessed by Professor Abigail Aguilar, curator. Annona squamosa L. was identified in situ by Juan Carlos Juarez Delgado from HUMO Herbarium, Autonomous University of Morelos (UAEM). Camellia sinensis (Yamamotoyama, Pomona, USA) was bought at a Japanese specialty store and used as a vegetal positive control (CsHAE).

2.3. Preparation of Hydroalcoholic Extracts. Vegetal materials (aerial parts, leaves, or seeds) were dried in a dark room at $25-30^{\circ} \mathrm{C}$ for 15 days. The dry material was ground to obtain 4-6 $\mathrm{mm}$ particles (diameter). Samples of $25 \mathrm{~g}$ of all these plants (20 g for Hintonia latiflora) were exhaustively extracted by maceration with $250 \mathrm{~mL}$ of an ethanol solution $(60 \%)$ at $50^{\circ} \mathrm{C}$ for 2 hours (three times). After filtration, the solvent was removed under reduced pressure distillation. Semisolid extracts were finally lyophilized and stored at $4^{\circ} \mathrm{C}$ in air-tight centrifuge tubes until needed. Most species produced yield over 20\% (Table 1).

2.4. Glucosidase Inhibition. Glucosidase inhibition assays were performed in quadruplicate as previously reported [12], at an extract concentration of $1 \mathrm{mg} / \mathrm{mL}$. In brief, cornstarch $(12.5 \mathrm{mg} / \mathrm{mL})$ was digested by crude enzyme (homogenate from Sprague Dawley rats' intestinal mucosa) at $37^{\circ} \mathrm{C}$ for 10 minutes and released glucose was quantified by a glucose oxidase-based clinical reagent (SPINREACT), following manufacturer's directions. All inhibitions were calculated as percentage of uninhibited control reactions.

2.5. Lipase Inhibition. Lipase inhibition assay was adapted from the method reported by Choi et al. [13]. The assay is based on the spectrophotometric quantification of free thiols with chromogenic 5, 5' -dithiobis(2-nitrobenzoic acid) (DTNB, Ellman's reagent), released by porcine pancreatic lipase from the 2,3-dimercapto-1-propanol tributyrate substrate (DMPTB, 97\%).

The reaction mixture contained $0.2 \mathrm{mM}$ DMPTB in 50 mM TRIS-HCl, pH 7.2, $2 \mathrm{mM} \mathrm{CaCl}_{2}, 0.1 \mathrm{M} \mathrm{NaCl}, 0.06 \%$ Triton X-100, and $0.8 \mathrm{mM}$ DTNB (in DMSO).

The porcine lipase was prepared as a stock at $10 \mathrm{mg} / \mathrm{mL}$ in TRIS-HCl $20 \mathrm{mM}, \mathrm{pH}$ 6.2, bovine serum albumin (BSA; $1 \mathrm{mg} / \mathrm{mL}$ ) and $0.1 \mathrm{M} \mathrm{NaCl}$, and stored at $-80^{\circ} \mathrm{C}$. The working samples of enzyme were diluted to $2 \mathrm{mg} / \mathrm{mL}$ in BSA $(1 \mathrm{mg} / \mathrm{mL})$, kept at $4^{\circ} \mathrm{C}$, and were used during $4-5$ hours. The assays were performed at $37^{\circ} \mathrm{C}$ and were started by adding 10 microliters of enzyme solution to 790 microliters of reaction mix, containing $0.25 \mathrm{mg} / \mathrm{mL}$ of plant extract in $50 \%$ DMSO or controls. The absorbance changes were recorded for up to 6 minutes at $412 \mathrm{~nm}$, plotted in Excel (Microsoft), and the initial slope was employed as the velocity of the reaction.

2.6. HPLC Analysis. Solutions ( $3 \mathrm{mg} / \mathrm{mL}$ ) of the most active extracts were analyzed using a HPLC system (Waters Co., Milford, MA, USA) with a photodiode array detector (Waters 2996). Separation was carried out using a RP-18 Supersphere (Merck) column $(120 \mathrm{~mm} \times 4 \mathrm{~mm} ; 5 \mu \mathrm{m})$ with the following solvent ratios for the mobile phase, where solvent $\mathrm{A}$ is water and solvent $\mathrm{B}$ corresponds to acetonitrile: $\mathrm{A}: \mathrm{B}=$ $100: 0$ (0-3 min); $90: 10$ (4-5 min); $80: 20$ (6-9); $0: 100$ (10$13 \mathrm{~min}) ; 100: 0$ (14-15 $\mathrm{min})$. The flow rate was $1 \mathrm{~mL} / \mathrm{min}$ and detection wavelength was scanned at 190-600 nm. The major compounds were analyzed according to their UV spectra and retention time.

\section{Results}

The Ethnobotanical Veracruz Atlas [8] listed 49 species as "antidiabetic" while Aguilar and Xolalpa [9] and AndradeCetto and Heinrich [10] reported 178 and 306 species, respectively. Romero-Cerecero [11] reports 64 species used in the state of Morelos. Ludwigia octovalvis ("clavillo") was found to be mentioned as a species of emerging local use by some diabetic patients and plant dealers. Species mentioned in at least two sources were selected, acquired, and processed to obtain their hydroalcoholic extract.

The test concentration of the extracts was adjusted to obtain a $0-85 \%$ range of glucosidase inhibition. As shown in Table 1, the vegetal positive control using $C$. sinensis hydroalcoholic extract (CsHAE) inhibited $\alpha$-glucosidase activity 
TAвLE 1: Alpha-glucosidase and lipase inhibition of 23 medicinal plants used in Mexico for diabetes trearment.

\begin{tabular}{|c|c|c|c|c|}
\hline Scientific name & Local name & Yield \% & glucosidase $\%$ inhibition $^{\mathrm{a}}$ & Lipase $\%$ inhibition $^{\mathrm{b}}$ \\
\hline Acacia farnesiana (L.) Willd. & Huizache & 19.0 & $21.0 \pm 3.1$ & $26.6 \pm 1.76$ \\
\hline Achillea millefolium $\mathrm{L}$. & Milenrama & 27.3 & $52.3 \pm 4.1$ & $11.5 \pm 2.67$ \\
\hline Annona squamosa $\mathrm{L}$. & Anona & 16.4 & $22.3 \pm 1.6$ & $14.4 \pm 3.0$ \\
\hline Artemisia absinthium L. & Ajenjo & 15.5 & $67.7 \pm 3.7$ & $25.2 \pm 2.14$ \\
\hline Bidens pilosa L. & Aceitilla & 16.2 & $41.8 \pm 1.7$ & $13.6 \pm 3.61$ \\
\hline Calea ternifolia Kunth & Prodigiosa & 18.4 & $61.1 \pm 1.7$ & $11.8 \pm 0.18$ \\
\hline Camellia sinensis (L.) Kuntze & Te Verde & 35.5 & $85.0 \pm 1.3$ & $45.6 \pm 4.31$ \\
\hline Cecropia obtusifolia Bertol. & Guarumbo & 18.6 & $28 \pm 1.9$ & $19.9 \pm 5.4$ \\
\hline Hintonia latiflora (Sessé \& Moc. ex DC.) Bullock & Copalchi & 41.3 & $39.2 \pm 3.5$ & $14.4 \pm 2.8$ \\
\hline Crataegus mexicana Moc. \& Sessé ex DC. & Tejocote & 27.5 & $38.6 \pm 1.6$ & ppt \\
\hline Eucalyptus globulus Labill. & Eucalipto & 22.5 & $33.6 \pm 3.0$ & $11.3 \pm 0.4$ \\
\hline Guazuma ulmifolia Lam. & Guacima & 15.4 & $23.0 \pm 3.9$ & $13.1 \pm 1.37$ \\
\hline Iostephane heterophylla (Cav.) Benth. & Zacapal & 24.3 & $60.6 \pm 1.5$ & $15.1 \pm 1.91$ \\
\hline Justicia spicigera Schltdl. & Muicle & 22.1 & $0.4 \pm 1.5$ & $12.7 \pm 4.3$ \\
\hline Lepidium virginicum $\mathrm{L}$. & Lentejita & 17.4 & $18.0 \pm 1.1$ & $9.6 \pm 1.2$ \\
\hline Ludwigia octovalvis (Jacq.) P.H.Raven & Clavillo & 37.0 & $82.7 \pm 1.9$ & $31.4 \pm 4.31$ \\
\hline Marrubium vulgare L. & Marrubio & 19.4 & $31.1 \pm 2.3$ & $1.8 \pm 2.5$ \\
\hline Persea americana Mill. & Aguacate & 27.8 & $17.9 \pm 2.9$ & $6.3 \pm 1.5$ \\
\hline Piper sanctum Miq. & Hoja santa & 22.2 & $10.5 \pm 0.8$ & $15.1 \pm 2.2$ \\
\hline Psidium guajava L. & Guayaba & 24.5 & $39.5 \pm 3.0$ & ppt \\
\hline Ricinus communis $\mathrm{L}$. & Higuerilla & 24.3 & $58.0 \pm 1.9$ & $14.4 \pm 2.1$ \\
\hline Tamarindus indica L. & Tamarindo & 18.8 & $30.1 \pm 2.2$ & ppt \\
\hline Taraxacum officinale Webb & Diente de León & 22.1 & $12.0 \pm 1.5$ & $5.0 \pm 1.3$ \\
\hline Tecoma stans (L.) Juss. ex Kunth & Tronadora & 25.6 & $32.3 \pm 1.7$ & $27.2 \pm 5.3$ \\
\hline
\end{tabular}

${ }^{a}$ Percentage of $\alpha$-glucosidase inhibition was calculated at $t=10 \mathrm{~min}$, whereby the reaction $=($ mean free glucose in sample/mean free glucose in uninhibited control) $\times 100$.

bercentage of lipase inhibition was calculated using the slope at $t=2-5 \mathrm{~min}$, whereby the reaction $=$ (mean slope in sample/mean slope in uninhibited control) $\times 100$.

ppt: sample precipitation strongly interfered with lipase assay.

significantly $\left(\mathrm{IC}_{50}=299 \mu \mathrm{g} / \mathrm{mL}\right)$. Acarbose displayed $>95 \%$ inhibition at $10 \mu \mathrm{g} / \mathrm{mL}$.

We chose an initial concentration of $1 \mathrm{mg} / \mathrm{mL}^{-1}$ for the screening stage. The most active species (inhibition > $50 \%$, Table 1) were further tested at a lower concentration $\left(0.5 \mathrm{mg} / \mathrm{mL}^{-1}\right.$, Table 2$)$ and the two species with the highest inhibitory activity (L. octovalvis and Iostephane heterophylla Benth) were compared with the control (Camellia sinensis) in a dose-response curve (Figure 1). L. octovalvis showed the lowest $\mathrm{IC}_{50}\left(202 \mu \mathrm{g} \mathrm{mL}^{-1}\right)$, followed by $C$. sinensis $\left(299 \mu \mathrm{g} \mathrm{mL}^{-1}\right)$ and I. heterophylla $\left(509 \mu \mathrm{g} \mathrm{mL}^{-1}\right)$, respectively (Table 2).

Then we examined the effects of all selected extracts on lipase inhibition activity evaluated at $0.25 \mathrm{mg} / \mathrm{mL}$. In this case, the pharmaceutical drug orlistat and CsHAE were used as reference. An initial concentration of $0.25 \mathrm{mg} / \mathrm{mL}$ was chosen for all plant-screening purposes, since higher concentrations of some extracts strongly absorbed at the employed wavelength. Under these conditions, the reference extract (C. sinensis) displayed $45.6 \%$ inhibition of this digestive enzyme. The most active species were compared with the control (Camellia sinensis) in a dose-response curve (Figure 2). C. sinensis, L. octovalvis, and Tecoma stans (L.)

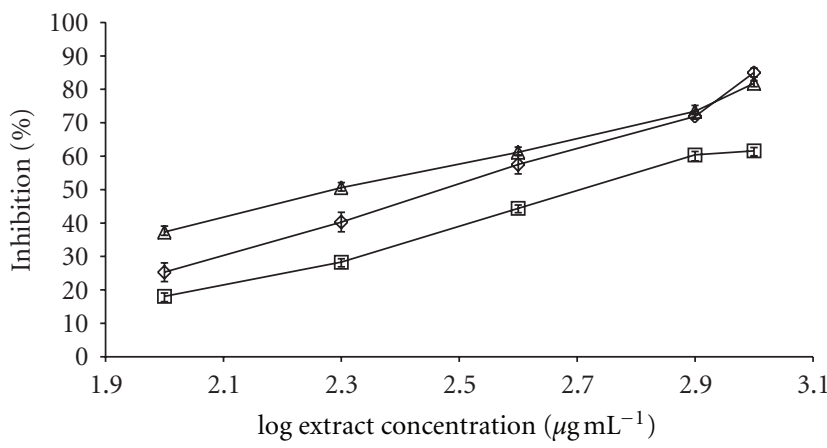

FIGURE 1: Dose-response curves of the hydroalcoholic extracts from Camellia sinensis $(\bigcirc)$, Ludwigia octovalvis $(\triangle)$, and Iostephane heterophylla $(\square)$ leaves in the in vitro $\alpha$-glucosidase inhibition model. $x$-axis $=\log$ concentration in $\mu \mathrm{g} \cdot \mathrm{mL}^{-1} ; y$-axis $=$ inhibition percentage.

H.B. \& K. gave similar IC 50 values $(310,288$, and $320 \mu \mathrm{g} / \mathrm{mL})$. In these conditions, orlistat gave an $\mathrm{IC}_{50}=142 \mathrm{ng} / \mathrm{mL}$.

The extracts of the reference plant and the most active species: Camellia sinensis, Ludwigia octovalvis, Iostephane heterophylla, Acacia. farnesiana, Artemisia absinthium, and 
TABLe 2: $\alpha$-glucosidase the 10 most active medicinal plants used in Mexico for diabetes treatment.

\begin{tabular}{lccc}
\hline Scientific name & Local name & $\alpha$-glucosidase $\%$ inhibition $\left(0.5 \mathrm{mg} \mathrm{mL}^{-1}\right)$ & $\mathrm{IC}_{50}\left(\mu \mathrm{g} \mathrm{mL}^{-1}\right)$ \\
\hline Artemisia absinthium & Ajenjo & $45.0 \pm 1.7$ & n.d. \\
Achillea millefolium & Milenrama & $22.9 \pm 1.7$ & n.d. \\
Calea ternifolia & Prodigiosa & $39.8 \pm 2.1$ & n.d. \\
Camellia sinensis* & Te Verde & $\mathbf{6 7 . 3} \pm \mathbf{0 . 8}$ & $\mathbf{2 9 9}$ \\
Iostephane heterophylla & Zacapal & $51.4 \pm 2.5$ & 509 \\
Ludwigia octovalvis & Clavillo & $\mathbf{6 1 . 3} \pm \mathbf{1 . 4}$ & $\mathbf{2 0 2}$ \\
Ricinus communis & Higuerilla & $43.4 \pm 2.4$ & n.d. \\
\hline
\end{tabular}

n.d.: no determined, ${ }^{*}$ reference plant drug control. Percentage of $\alpha$-glucosidase inhibition was calculated at $t=10$ min as $100 \%$ reaction, whereby the reaction $=($ mean free glucose in sample $/$ mean free glucose in control $) \times 100$.

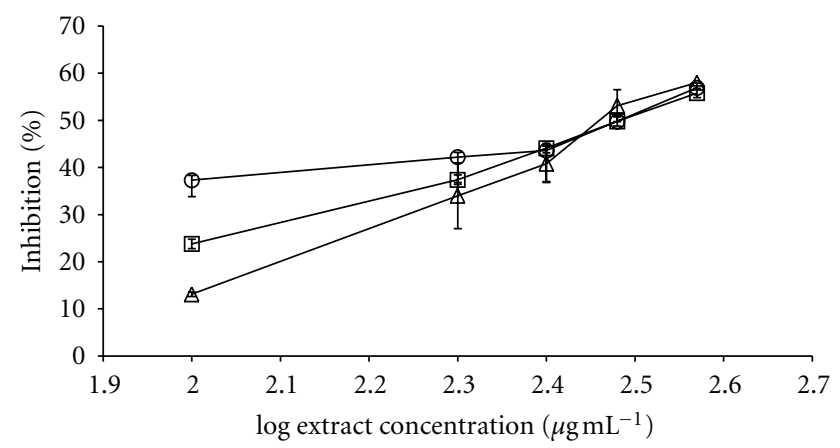

FIGURE 2: Dose-response curves of the hydroalcoholic extracts from Camellia sinensis $(\bigcirc)$, Ludwigia octovalvis $(\triangle)$, and Tecoma stans $(\square)$ leaves in the in vitro lipase inhibition model. $x$-axis $=\log$ concentration in $\mu \mathrm{g} \cdot \mathrm{mL}^{-1} ; y$-axis= inhibition percentage.

Tecoma stans were analyzed by DAD-HPLC. The obtained spectra were interpreted by the presence of $\lambda \max 220,255$, $275,325,340$, and/or $360 \mathrm{~nm}$. The profile of $C$. sinensis shows $\lambda \max =220$ and $275 \mathrm{~nm}$, associated with catechins, compounds widely reported in this species [14]. Interestingly, $L$. octovalvis has peaks with similar UV absorption spectrum $(\lambda \max =220$ and $275 \mathrm{~nm})$, and also others characteristic of flavonols $(\lambda \max =210,255$, and $355 \mathrm{~nm}$; Figure 3 ). Both species show very high inhibition activities. The $A$. farnesiana and T. stans UV spectrum profiles show flavonol and flavone patterns $(\lambda \max =210,255,350 \mathrm{~nm}$ and $210,275,330 \mathrm{~nm}$ resp.), while A. absinthium, C. ternifolia, and I. heterophylla havea profile with peaks associated with caffeoyl derivatives $(\lambda \max =210$ and $325 \mathrm{~nm})[15,16]$.

\section{Discussion}

The scientific literature contains many reports of the in vivo antidiabetic activities (mostly hypoglycemic or antihyperglycemic) of medicinal plants. Nevertheless, only few of them describe some action mechanism present in the extract. This survey was designed to search for the inhibition of two enzyme activities in a sample of ethnomedically selected species, considering that they may be part of their antidiabetic properties. This approach is aimed at mildly reducing carbohydrate and lipid digestion and absorption, thus decreasing the hyperglycemia and hyperlipemia peaks. Both measures have been shown to be useful in decreasing the risk of developing diabetes $[17,18]$.

Besides previously reported species, we obtained information from sources in the southern area of the state of Morelos, on the use of Ludwigia octovalvis as an antidiabetic. This phenomenon may reflect the empirical search of the population to find additional therapeutic resources for diabetes control.

Two species were found with the highest levels of inhibition in both activities: Artemisia absinthium (ajenjo) and $L$. octovalvis (clavillo). The first plant has many traditional uses: It is reported as an antiparasitic, antimicrobial, and hepatoand neuroprotective. While this plant has been reported as rich in flavonols (kaempferol and quercetagetin derivatives) and essential oils like thujone, in this work we mainly found a high level of caffeoyl derivatives [19].

L. octovalvis (Jussiaea suffruticosa) was reported by Murugesan et al. [20] as having antidiabetic activities in normal and alloxanized rats, but no action mechanism was proposed and no further research has been published to our knowledge. In the state of Morelos, it is employed as an infusion for dysuria due to prostate hyperplasia; this use is shared by some regions of the neighboring state of Guerrero. This plant contains C-glycosylated flavones like orientin, isoorientin, vitexin, and isovitexin, mainly [21]. According to our results, we found this kind of flavonoids in the hydroalcoholic extract, together with a high concentration of compounds with $\lambda=220,275 \mathrm{~nm}$. They could correspond to catechins [14].

Concerning the lipase inhibiting activity, three species yielded similar high values: Artemisia absinthium, Acacia farnesiana (L.) Willd, and Tecoma stans (25.2, 26.6, and $27.2 \%$ inhibition, resp.). Recently, Ikarashi et al. reported the presence of both inhibitory activities in the bark of Acacia mearnsii [22], identifying a catechin-rich preparation as the main active fraction. We found that leaves of $A$. farnesiana are also very active in lipase inhibition but low in glucosidase inhibition activities. In this case, the active extract mainly contains flavonol and flavone-like peaks $(\lambda \max =210,255,355 ; 216,271,336 \mathrm{~nm})$ [23]. Tecoma stans has been employed and studied as an antidiabetic for decades; we described the presence of glucosidase activity [12] and now we report the presence of a strong lipase 


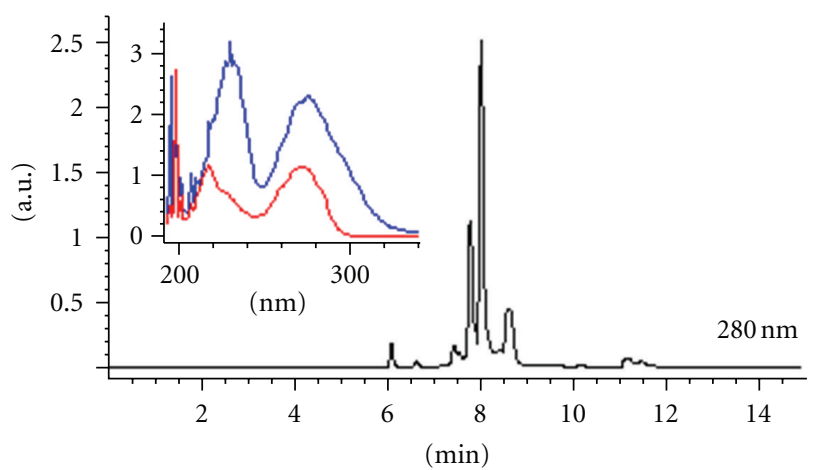

(a)

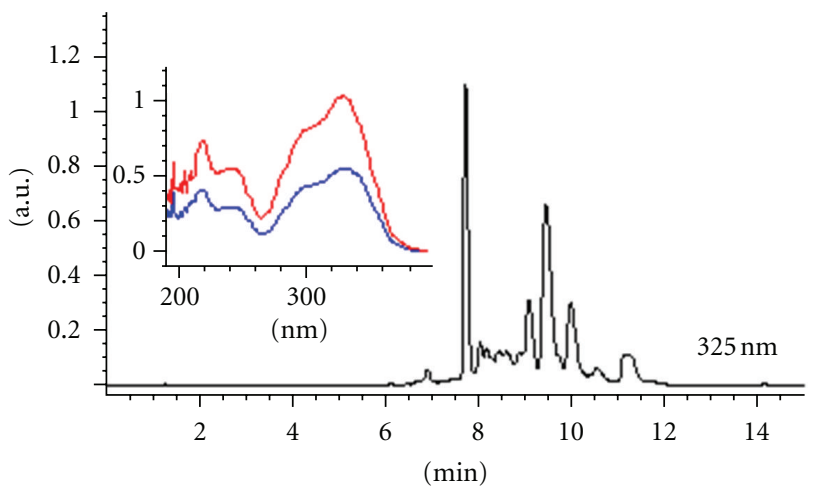

(c)

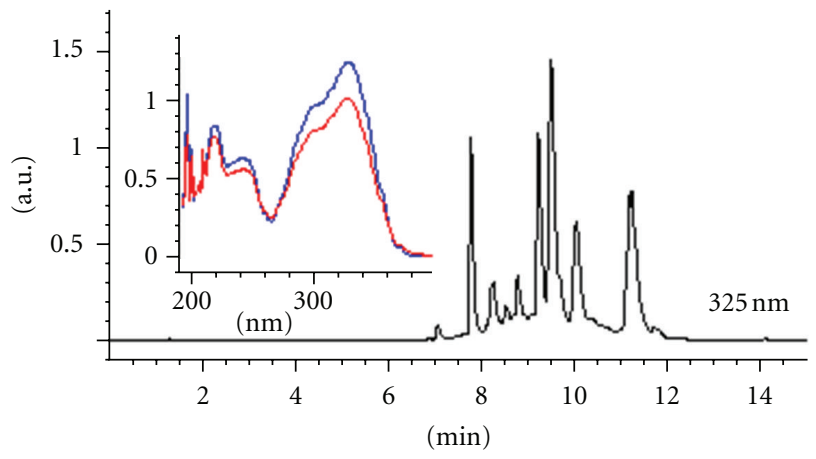

(e)

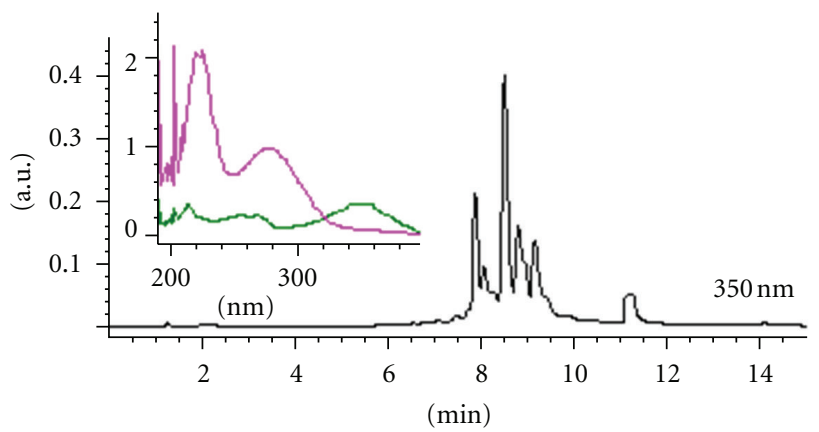

(b)

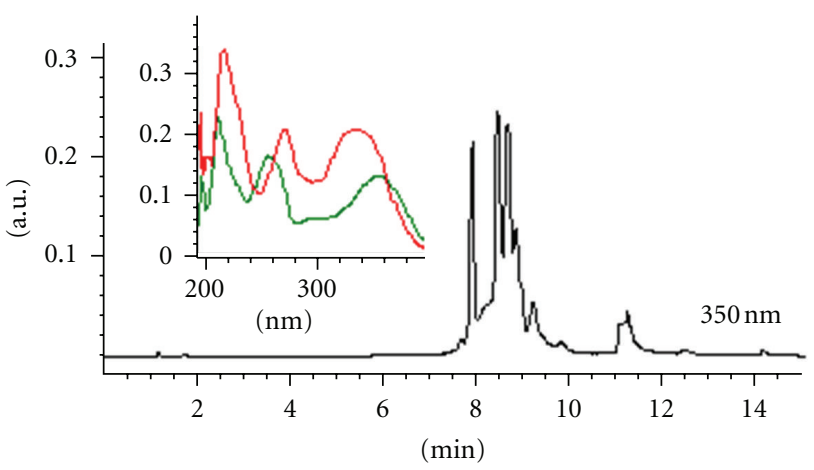

(d)

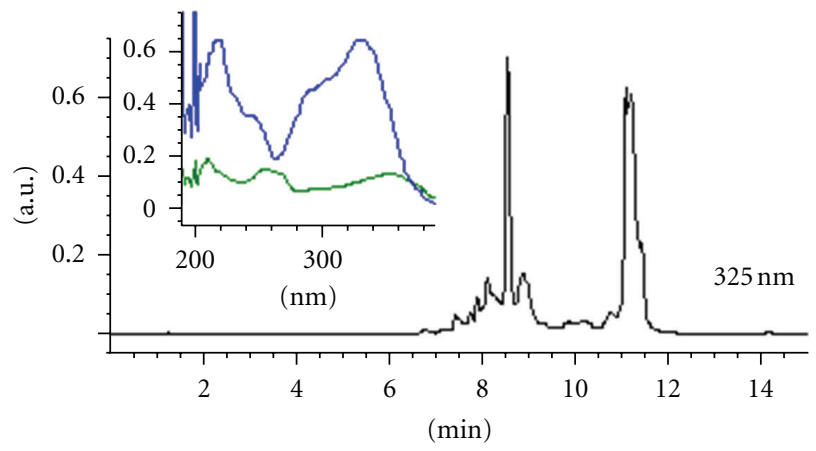

(f)

FIGURE 3: HPLC chromatograms of the reference plant and the most active species-(a) C. sinensis, (b) L. octovalvis, (c) I. heterophylla, (d) A. farnesiana, (e) A. absinthium, and (f) T. stans.

inhibiting activity. Chromatographic analysis of this plant indicated a major concentration of caffeoyl derivatives and flavone-like compounds.

The in vitro assay employed allowed us to identify highly active species in a fast, economical, and sensitive way. This approach does not substitute in vivo testing but acts as a prefilter of the chosen enzymatic activity and directs the animal models that, otherwise, may render negative results [24]. The lipase assay employed is sensitive and is not affected by zwitterionic compounds present in the extracts, but may be interfered by colored substances and free thiols, limiting its usefulness in some botanical species.

In conclusion these results support the ethnomedical use of some plants reported by the Mexican traditional medicine and yield information about one of their action mechanisms that could be of immediate use to traditional healers. Although the major compounds in the most active species correspond to catechins, flavonols, flavones, and caffeoyl derivatives, these antidiabetic plants are being subjected to a detailed phytochemical and pharmacological study to identify their active compounds.

\section{Acknowledgments}

The authors are indebted to Abigail Aguilar Contreras, M.S., Director of IMSSM Herbarium, and to Juan Carlos Juarez Delgado, from the HUMO Herbarium (University of Morelos), for their support in identifying the plant species. 
This paper is taken in part from the Ph.D. thesis of Guillermo Ramírez.

\section{References}

[1] G. Danaei, M. M. Finucane, Y. Lu et al., "National, regional, and global trends in fasting plasma glucose and diabetes prevalence since 1980: Systematic analysis of health examination surveys and epidemiological studies with 370 country-years and 2.7 million participants," The Lancet, vol. 378, no. 9785, pp. 31-40, 2011.

[2] S. Nair and J. P. H. Wilding, "Sodium glucose cotransporter 2 inhibitors as a new treatment for diabetes mellitus," Journal of Clinical Endocrinology and Metabolism, vol. 95, no. 1, pp. 3442, 2010.

[3] R. I. Meijer, B. A. Van Wagensveld, C. E. Siegert, E. C. Eringa, E. H. Serné, and Y. M. Smulders, "Bariatric surgery as a novel treatment for type 2 diabetes mellitus: a systematic review," Archives of Surgery, vol. 146, no. 6, pp. 744-750, 2011.

[4] J. M. Chehade and A. D. Mooradian, "A rational approach to drug therapy of type 2 diabetes mellitus," Drugs, vol. 60, no. 1, pp. 95-113, 2000.

[5] H. Fujita, T. Yamagami, and K. Ohshima, "Long-term ingestion of a fermented soybean-derived Touchi-extract with $\alpha$ glucosidase inhibitory activity is safe and effective in humans with borderline and mild type-2 diabetes," Journal of Nutrition, vol. 131, no. 8, pp. 2105-2108, 2001.

[6] K. A. Grove and J. D. Lambert, "Laboratory, epidemiological, and human intervention studies show that tea (Camellia sinensis) may be useful in the prevention of obesity," Journal of Nutrition, vol. 140, no. 3, pp. 446-453, 2010.

[7] V. Poitout, J. Amyot, M. Semache, B. Zarrouki, D. Hagman, and G. Fontés, "Glucolipotoxicity of the pancreatic beta cell," Biochimica et Biophysica Acta, vol. 1801, no. 3, pp. 289-298, 2010.

[8] L. Cano-Asseleih, Flora Medicinal de Veracruz. I. Inventario Etnobotánico, Universidad Veracruzana, Xalapa, Mexico, 1997.

[9] A. Aguilar-Contreras and S. Xolalpa-Molina, "La herbolaria mexicana en el tratamiento de la diabetes," Ciencia, vol. 53, pp. 24-35, 2002.

[10] A. Andrade-Cetto and M. Heinrich, "Mexican plants with hypoglycaemic effect used in the treatment of diabetes," Journal of Ethnopharmacology, vol. 99, no. 3, pp. 325-348, 2005.

[11] O. Romero-Cerecero, H. Reyes-Morales, L. AguilarSantamaría, M. Huerta-Reyes, and J. Tortoriello-Garcia, "Use of medicinal plants among patients with diabetes mellitus type 2 in Morelos, Mexico," Boletin Latinoamericano y del Caribe de Plantas Medicinales y Aromaticas, vol. 8, no. 5, pp. 380-388, 2009.

[12] R. R. Ortiz-Andrade, S. García-Jiménez, P. Castillo-España, G. Ramírez-Ávila, R. Villalobos-Molina, and S. Estrada-Soto, " $\alpha$-Glucosidase inhibitory activity of the methanolic extract from Tournefortia hartwegiana: an anti-hyperglycemic agent," Journal of Ethnopharmacology, vol. 109, no. 1, pp. 48-53, 2007.

[13] S. J. Choi, J. M. Hwang, and S. I. Kim, "A colorimetric microplate assay method for high throughput analysis of lipase activity," Journal of Biochemistry and Molecular Biology, vol. 36, no. 4, pp. 417-420, 2003.

[14] J. J. Dalluge and B. C. Nelson, "Determination of tea catechins," Journal of Chromatography A, vol. 881, no. 1-2, pp. 411-424, 2000.
[15] T. Horie, Y. Kawamura, H. Yamamoto, T. Kitou, and K. Yamashita, "Synthesis of 5,8-dihydroxy-6,7-dimethoxyflavones and revised structures for some natural flavones," Phytochemistry, vol. 39, no. 5, pp. 1201-1210, 1995.

[16] P. C. Lyons, K. V. Wood, and R. L. Nicholson, "Caffeoyl ester accumulation in corn leaves inoculated with fungal pathogens," Phytochemistry, vol. 29, no. 1, pp. 97-101, 1990.

[17] J. S. Torgerson, J. Hauptman, M. N. Boldrin, and L. Sjöström, "XENical in the Prevention of Diabetes in Obese Subjects (XENDOS) Study: a randomized study of orlistat as an adjunct to lifestyle changes for the prevention of type 2 diabetes in obese patients," Diabetes Care, vol. 27, no. 1, pp. 155-161, 2004.

[18] J. L. Chiasson, R. G. Josse, R. Gomis, M. Hanefeld, A. Karasik, and M. Laakso, "Acarbose treatment and the risk of cardiovascular disease and hypertension in patients with impaired glucose tolerance. The STOP-NIDDM Trial," Journal of the American Medical Association, vol. 290, no. 4, pp. 486494, 2003.

[19] D. W. Lachenmeier, "Wormwood (Artemisia absinthium L.)A curious plant with both neurotoxic and neuroprotective properties?" Journal of Ethnopharmacology, vol. 131, no. 1, pp. 224-227, 2010.

[20] T. Murugesan, B. Rao, S. Sinha, S. Biswas, M. Pal, and B. P. Saha, "Anti-diabetic activity of Jussiaea suffruticosa extract in rats," Pharmacy and Pharmacology Communications, vol. 6, no. 10, pp. 451-453, 2000.

[21] J. E. Averett, E. M. Zardini, and P. C. Hoch, "Flavonoid systematics of ten sections of Ludwigia (Onagraceae)," Biochemical Systematics and Ecology, vol. 18, no. 7-8, pp. 529-532, 1990.

[22] N. Ikarashi, R. Takeda, K. Ito, W. Ochiai, and K. Sugiyama, "The inhibition of lipase and glucosidase activities by acacia polyphenol," Evidence-based Complementary and Alternative Medicine, vol. 2011, Article ID 272075, 5 pages, 2011.

[23] M. Nikolova and D. Veličković, "Phenological variations in the surface flavonoids of Artemisia vulgaris L. and Artemisia absinthium L.," Turkish Journal of Botany, vol. 31, no. 5, pp. 459-462, 2007.

[24] L. Aguilar-Santamaría, G. Ramírez, P. Nicasio, C. AlegríaReyes, and A. Herrera-Arellano, "Antidiabetic activities of Tecoma stans (L.) Juss. ex Kunth," Journal of Ethnopharmacology, vol. 124, no. 2, pp. 284-288, 2009. 


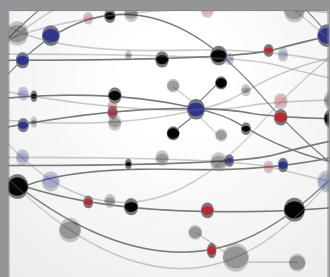

The Scientific World Journal
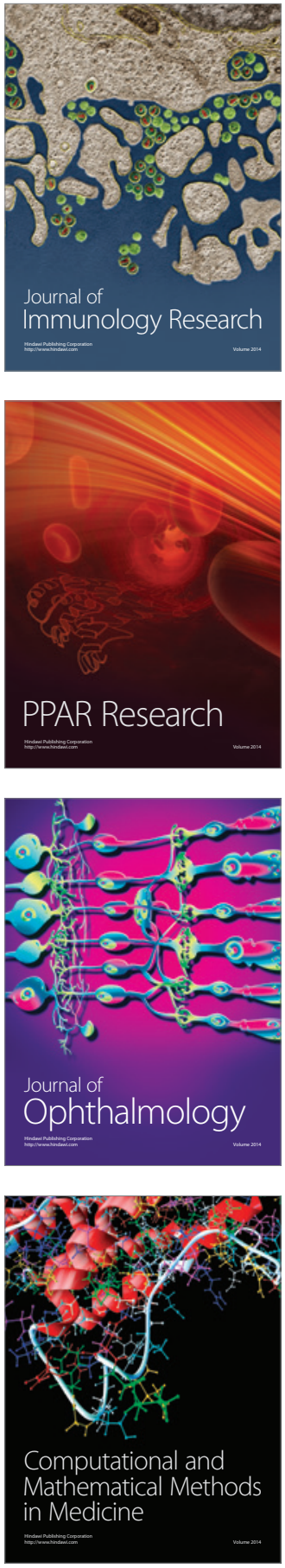

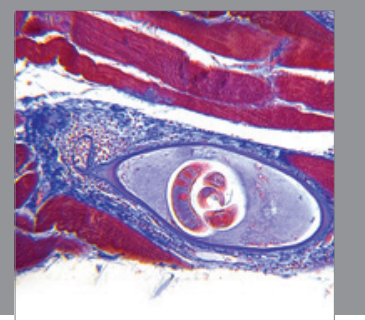

Gastroenterology

Research and Practice
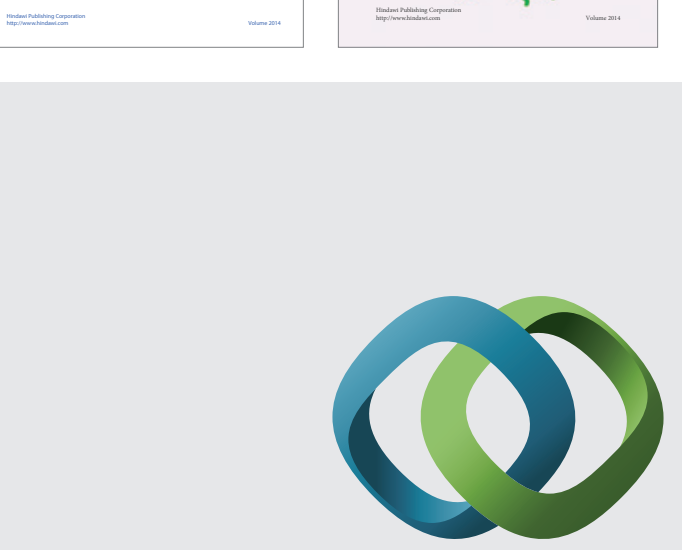

\section{Hindawi}

Submit your manuscripts at

http://www.hindawi.com
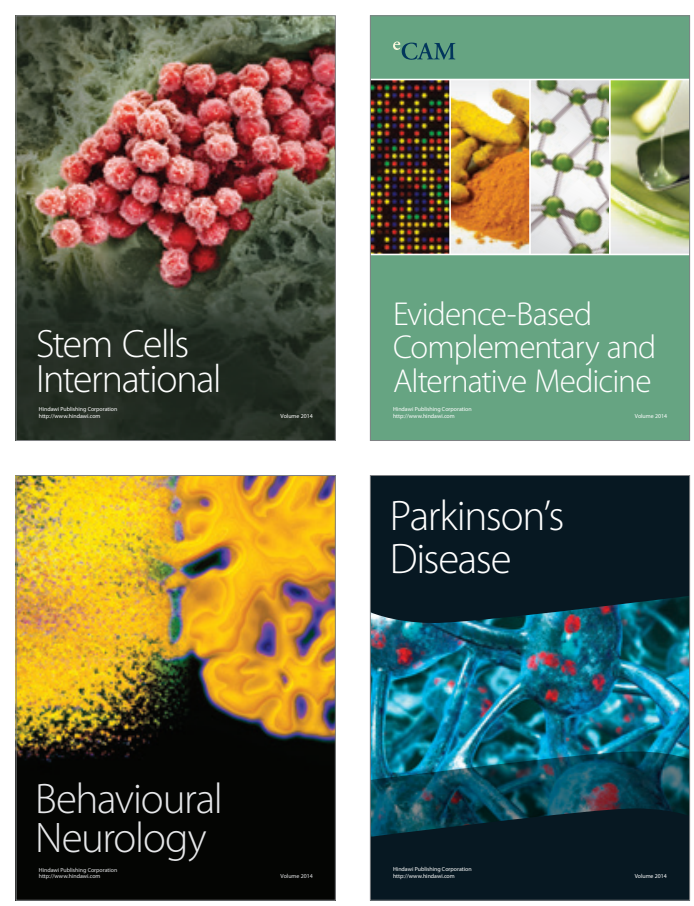

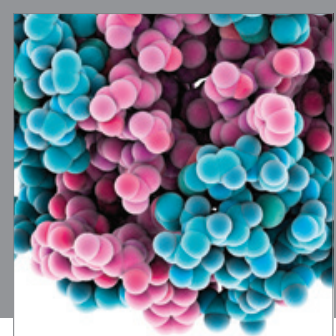

Journal of
Diabetes Research

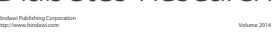

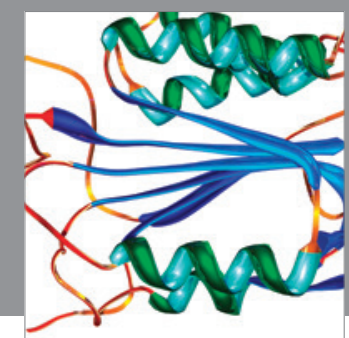

Disease Markers
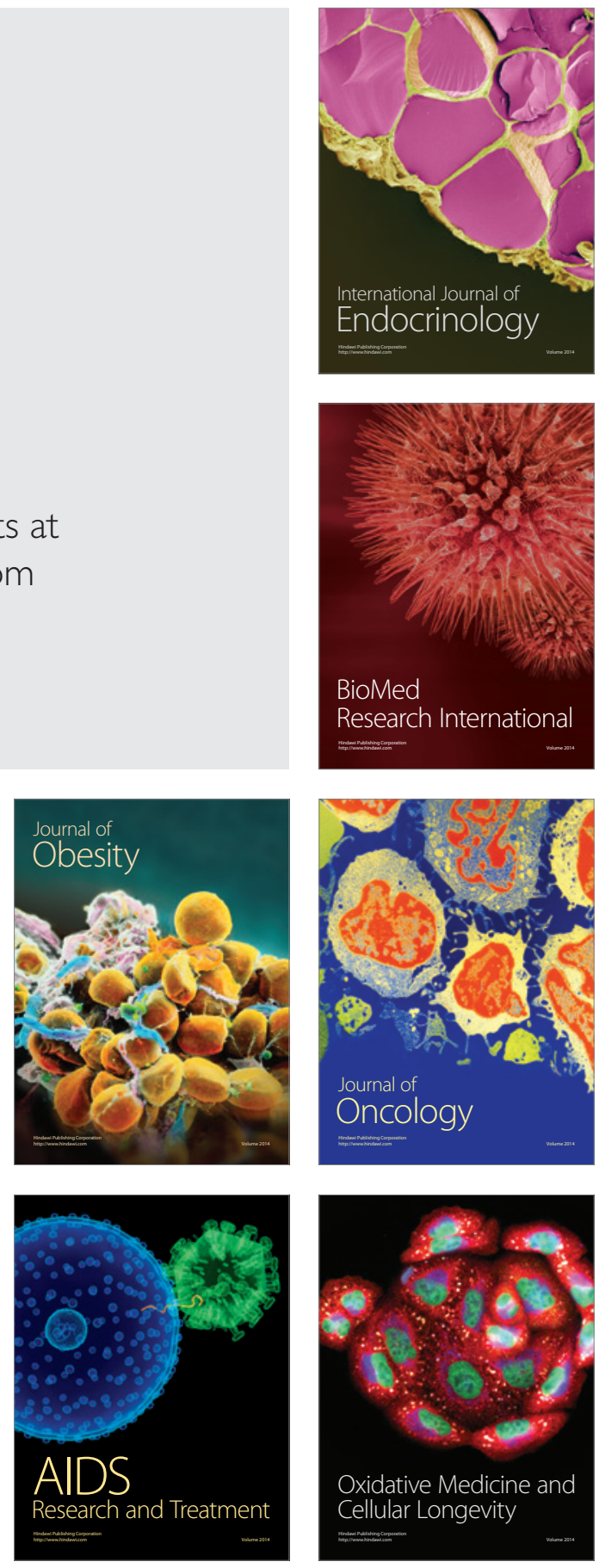